Oñati Socio-legal Series, v. 8, n. 8 (2018) - Sex Work in the Early 21st Century - Law, Policy and Reality

ISSN: 2079-5971

\title{
A Debate on Prostitution in Spain: Barcelona's Bylaw on Coexistence
}

Paula ArCe BeCERRA*

Arce Becerra, P., 2018. A Debate on Prostitution in Spain: Barcelona's Bylaw on Coexistence. Oñati Socio-legal Series [online], 8 (8), 1197-1214. Received: 14-07-2017; Accepted: 10-04-2018. Available from: https://doi.org/10.35295/osls.iisl/0000-0000$\underline{0000-0984}$

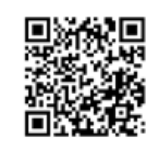

\begin{abstract}
The article describes and analyzes the Spanish policies to deal with street prostitution since the end of 2005 when Barcelona's Bylaw on Coexistence was passed. This local bylaw prohibits and sanctions offering, negotiating or requesting of sexual services in public spaces. Most Spanish municipalities have adopted similar bylaws prohibiting prostitution in the street in recent years. The article aims to analyze the impact of these regulations and their implementation on the rights of people working in prostitution. In order to achieve this it takes into consideration contributions that feminist movements have made to debates on prostitution and public policies.
\end{abstract}

\section{Key words}

Prostitution; sex work; human rights

\section{Resumen}

El presente artículo describe y analiza las políticas que se han venido implantando en España para tratar la prostitución en la calle, desde que, a finales de 2005, el Ayuntamiento de Barcelona aprobara la Ordenanza de Medidas para Fomentar y Garantizar la Convivencia Ciudadana. Dicha ordenanza prohíbe y castiga la oferta, negociación o solicitud de servicios sexuales en espacios públicos. Muchas ciudades españolas han adoptado ordenanzas similares en años recientes. El artículo pretende analizar el impacto de estas regulaciones y de su implementación sobre los derechos de las personas que trabajan en la prostitución. Para ello, toma en consideración aportaciones realizadas por movimientos feministas a los debates sobre prostitución y políticas públicas.

\section{Palabras clave}

Prostitución; trabajo sexual; derechos humanos

This article was carried out within the framework of the Interuniversity Doctoral Program in Gender Studies: Cultures, Societies and Policies, of the Universidad Autónoma de Barcelona.

* Paula Arce Becerra is a member of Grup de reserca Antìgona. Contact details: Departament de Ciència Política i Dret Públic, Àrea de Filosofia del Dret. Universitat Autònoma de Barcelona, Edifici B - Despatx B2/124. Campus de la UAB 08193 Bellaterra (Cerdanyola del Vallès). Barcelona, Spain. Email address: Paula.Arce@uab.cat 


\section{Table of contents / Índice}

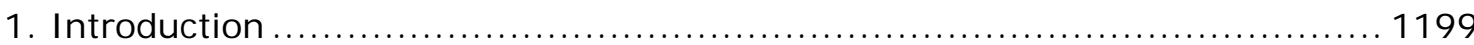

2. Models of public policies dealing with street prostitution ..................... 1199

2.1. Regulatory models ................................................. 1200

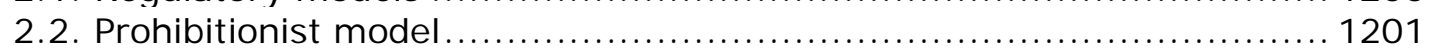

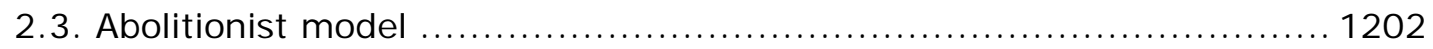

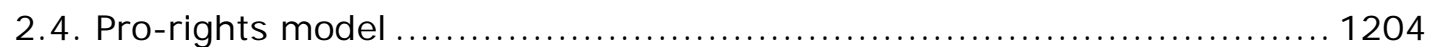

3. Spanish model: prostitution in Barcelona after the Bylaw on Coexistence.... 1205

3.1. The concept of civility and previous context to the passing of Barcelona's

Bylaw on Coexistence ...................................................... 1206

3.2. Content of the Bylaw on Coexistence related to the prohibition of the

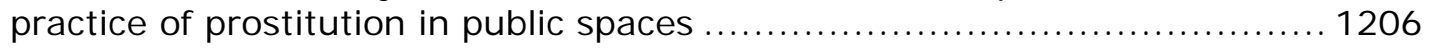

3.3. The grounds for the prohibition of prostitution in the bylaw ............. 1207

3.4. Appealing against the Bylaw on Coexistence.............................. 1208

3.5. Modification of the Bylaw on Coexistence ............................... 1209

3.6. Statistics published by the Barcelona Local Police in reference to the prohibition of prostitution in public spaces ................................. 1210

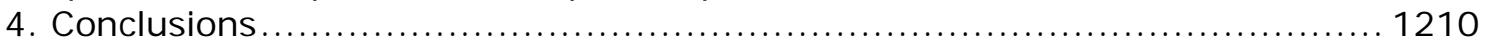

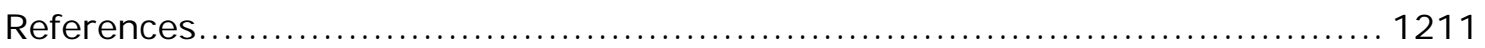




\section{I ntroduction}

The debate on how to approach the phenomenon of prostitution is one of the great historical debates addressed by feminist studies. It has been analyzed from two main perspectives in the feminist literature: on the one hand, abolitionist authors defend the eradication of prostitution as they conceive it as violence against women. And on the other hand, sex worker's rights movements and pro-right authors consider prostitution as a job and claim recognition of sex worker's rights. These two perspectives are usually considered as two points of view hardly reconcilable and have given rise to intense discussions within feminist movements.

This paper does not intend to cover the entire debate on the complex phenomenon of prostitution. It starts from the fact that both perspectives have a common concern for the possible violation of women's rights. The objective of this article is to study the implementation of Barcelona's Bylaw on Coexistence (Ajuntament de Barcelona [Barcelona City Council] 2005), as it has been the first regulation of prostitution in Spain since Franco's dictatorship, and has been a model of regulation transferred to most cities in Spain. Faced with the passivity of the Spanish government, municipalities have taken the initiative in regulating prostitution in the public space and have decided to carry out a policy of prohibition and administrative sanction for both prostitutes and their clients.

Although the objective of the article is limited to this particular subject, it must be said that a pro-rights perspective is assumed by the author as long as it is considered necessary to distinguish between prostitution or sex work and trafficking of human beings. Because of this necessary distinction between different realities, the author will use the words prostitution or sex work when referring to voluntary sexual paid intercourse between adults with no violence or coercion involved. Other realities such as forced prostitution or sexual paid intercourses with underage girls will be referred as trafficking in human beings.

To analyze the effects that Barcelona's bylaw has had on rights of sex workers, it has been considered appropriate to review literature published in Spain approaching the main existing theoretical public policies for prostitution as well as positive legislation dealing with prostitution in countries such as the Netherlands, Germany, Sweden or the United States. Afterwards, regulation of prostitution in Spain will be studied, paying attention to local bylaws, especially, Barcelona's Bylaw on Coexistence that prohibits prostitution in public spaces.

\section{Models of public policies dealing with street prostitution}

This paper intends to provide a theoretical basis to approach the different models of public policies that have been formulated to deal with prostitution and, specifically, with street prostitution. These models, that have been conceived from a theoretical perspective, are usually divided into four: regulatory, prohibitionist, abolitionist and pro-rights models. In order to know their characteristics the chapter explores the main feminist studies carried out in Spain that analyze them from a socio-juridical point of view.

After a brief description of the characteristics of each of these theoretical models the chapter analyzes the legislations and its implementation in a few chosen countries as they can be identified with each one of the models: Sweden as a prototype of neoabolitionist model, Germany as a regulatory model, and, finally, the United States as an example of the prohibitionist model. There is currently no state that has fully embraced a pro-rights model so it is not possible to analyze its implementation. The chapter studies some contributions that have been raised in the debate from this latter perspective. 


\subsection{Regulatory models}

Regulationism of prostitution appears in the mid-nineteenth century, in France, stemming from the concern of the medical sector for public hygiene and, in particular, venereal diseases (Nicolás 2008 p. 37). This model conceives prostitution as a natural fact and a minor and necessary evil: prostitution is seen both as a threat to health and something negative for society but, at the same time, something impossible to eradicate. Thus, it should be tolerated to avoid other evils. The State must therefore establish a set of rules that control the possible adverse effects of prostitution (i.e. the spread of diseases) and should keep the activity away from certain places (for example places frequented by minors), limiting its visibility (Rey et al. 2004, p. 18).

Throughout the nineteenth century, local bylaws were passed establishing controls on sex workers, but never on clients: for example, registration and medical cards were compulsory for prostitutes, as well as mandatory and intrusive gynecological inspections. Also this local rules persecuted clandestine prostitutes who worked out of the places of tolerance or prostitutes who contracted venereal diseases (Nicolás 2008, p. 38).

By the twentieth century this system was opposed by various sectors, especially by the abolitionist feminist movements which denounced the serious violation of rights implied by this rules and succeeded in repealing in many countries these oppressive controls on women prostitutes.

Actually, neo-reglamentarism is a concept that has been used to designate systems that tolerate prostitution and control the activity, generally, avoiding its visibility. Control is carried out especially through zoning practices that delimit spaces where the practice of prostitution is allowed, usually isolated places, outside residential areas (Mestre 2004, pp. 248-249). Control of the activity can be accompanied - or not - by the recognition of prostitution as a labor activity, but in any case this recognition would lack a gender perspective, and it would be based on the fallacy of equality between sex worker and client with no special protection for sex workers' rights (Nicolás 2008, p. 44).

The Netherlands was the first country to adopt the neo-regulationist model. ${ }^{1}$ In 2000 the Parliament approved a reform of the Penal Code which abolished the prohibition of the exploitation of voluntary sex work and increased penalties for trafficking on human beings for sexual exploitation. Since then, regulation of sexual services relies on a municipal system of licenses: each city is responsible for its policy on prostitution, and may prevent certain forms of exercise with the sole limitation of not completely banning it.

A few years after the Dutch Act, Germany followed the Dutch precedent by passing the Prostitution Act which came into force in January 2002. This law, which only consists of three articles, leaves the Länder ${ }^{2}$ with wide powers to regulate locally the conditions under which prostitution can be exercised. The law assumes the legalization of both self-employment and labor employment in the field of prostitution, while maintaining the criminal punishment of the exploitation of prostitution when the employer imposes conditions prohibited by law.

Between 2004 and 2006, Barbara Kavemann (2012, p. 99) carried out a study on the impacts of this law and has shown that although the new law make possible that employers hire sex workers, practically nobody works in prostitution as an employee.

\footnotetext{
${ }^{1}$ Some authors consider a fifth model, called labor model, in which they include the Dutch and German model. See for example Arella et al. 2007 or Maqueda 2009. However, it has been included in this model within the neo-regulationism because two special aspects can be identified: on the one hand and despite the legality of the activity of prostitution, it is regulated mainly by bylaws and local legislation, without there being a state law that homogenizes the conditions in which prostitution is exercised. Second, there is a zoning of activity through regulations limiting the spaces where prostitution can be exercised. In this sense, see Heim and Monfort 2004, Mestre 2004 and López and Mestre 2006.

${ }^{2}$ Germany is divided into 16 states or Länder.
} 
The author points out several causes that can explain these results: on the one hand, the employers consider that they assume all the economic risk of the business without any benefit because a labor contract would force them to pay a salary but does not oblige employees to perform a service. Likewise, criminal prohibition of exploitation encourages employers to avoid the employment relationship with prostitutes to guarantee the absence of criminal control. On the other hand, sex workers could not ask to be contracted because they would consider that a labor contract could lead to a loss of freedom, as they would not be able to choose time and place of work.

Other factors may discourage prostitutes from legalizing their situation, such as not wanting to lose their anonymity in order to avoid social stigmatization; the lack of incentives, for not seeing their rights sufficiently protected; or strictly salary reasons i.e., their income is likely to be reduced when they join the general social security system or have to pay taxes. Also there is a special problem with foreign workers without a work and residence permit, as they are denied the possibility of regularizing their situation (Maqueda 2009, pp. 99-100).

Pia Covre (Member of the Committee for the Civil Rights of Prostitutes in Italy) very vehemently criticizes the undesirable effects that laws that regulate labor of prostitution may have for women in an irregular administrative situation. She states that the presence of migrant women is, nowadays, preponderant, and the new status of legalized sex workers would be a way of separating autochthonous prostitutes from all others. Sex workers, she affirms, would derive their rights from the recognition of prostitution as a work, whereas migrant women, as "non-right ones", would not have such recognition of rights, and they would end up in a parallel market controlled by mafias (Covre 2004, pp. 243-244).

Another criticism toward both Dutch and German laws is that they presume equality of conditions to negotiate between prostitutes and clients, not taking into account gender inequalities. In addition, it should be noted that sex workers' unions are still weak and have not had sufficient historical trajectory to maintain a strong position in negotiations. Therefore, they have not been able to effectively influence the conditions of sexual workers (Heim and Monfort 2004, p. 122, Kavemann 2012, p. 112).

However, as positive effects of these models that legalize prostitution, some authors point out that there is no doubt that they represent an improvement in the situation of sex workers (Maqueda 2009, p. 99). In this sense, Andrea Di Nicola, coordinator of the European Parliament's study on prostitution policies in 25 European Union Member States, stated that sex workers are more protected in a regulatory system, not only in terms of their safety and physical integrity but also because they can pay taxes, receive social assistance and, finally, are treated as regular workers with protection rights (Di Nicola 2007, p. 223).

\subsection{Prohibitionist model}

Prohibitionist model considers prostitution as a criminal offence. From this perspective prostitution is perceived as a deviant, immoral and offensive activity for public order. The transmission of venereal diseases or other ills and problems associated to prostitution are conceived as a responsibility of all persons involved in the purchase of sex: both prostitutes and clients are found equally responsible for them and are equally punished.

Women who engage in prostitution are considered deviant, depraved, immoral or greedy (for wanting to enrich themselves quickly and effortlessly). Sex workers are conceived as opposed to the positive normative model of women married with children and, in the same way, clients are seen as perverted people who put in danger the traditional role of family (López and Mestre 2006, p. 68).

Nowadays, few states declare expressly to follow a prohibitionist model; most formally adhere to the abolitionist system although many of them have multiple rules 
or practices that do criminalize the practice of prostitution (Arella et al. 2006 p. 30). For instance, the United States follows a prohibitionist model but also assumes an abolitionist model in the matter of human trafficking. In all states, except Nevada, to "engage in" or "solicit for" prostitution is conceived as a criminal offence. Thus, both pimps and clients as well as prostitutes are proscribed and punished under criminal law.

Prohibitionism seeks to eliminate prostitution, and aims to eradicate it by punishing prostitution, clients, and other people involved with the activity. Nonetheless, the studies that have evaluated the implementation of prohibitionist models show that they have never achieved this objective and, rather than eliminating prostitution, the illegal status of prostitutes has led them to rely on third parties who primarily profit from this activity to the detriment of the prostitutes themselves (Wijers 2004, p. 210).

Villacampa (2012, pp. 95-97) has analyzed the implementation of prohibitionist model in the United States and affirms that no positive results have been obtained: first, many economic resources have been invested to criminalize such behavior, and yet, prostitution ratios have not been reduced. ${ }^{3}$ Secondly, most severe penalties are imposed primarily to prostitutes, not to clients or pimps. In this regard, it should be noted that prostitutes have account for up to 90 per cent of people arrested under anti-prostitution laws. Finally, victims of trafficking in human beings are rarely identified as victims of a criminal offense because their prosecution as criminals themselves makes difficult to perceive them as possible victims of trafficking.

\subsection{Abolitionist model}

Abolitionism, as its name suggest, seeks the eradication of prostitution. It assumes prostitution is inconvenient for society because it perpetuates inequality between men and women. Both abolitionism and prohibitionism have the same goal of eradicating prostitution, but they differ in the means to achieve it. Abolitionism, unlike the prohibitionist perspective, doesn't criminalize prostitutes as they consider women engaged in prostitution as victims of patriarchal violence, while clients and pimps and other people who favor prostitution are found responsible of it and, therefore, penalized.

Heim (2011, pp. 236-243) distinguishes four different types within the abolitionist model. Her classification can be useful to understand the complexity of positions that are inscribed within the abolitionist movement. The first type is what she calls "classic abolitionism". It originated in England in the late nineteenth century and spread to the rest of Europe and other parts of the world until the first half of the twentieth century. Classic abolitionism fought against laws regulating prostitution under a regulationist model, such as intrusive gynecological inspections or arbitrary police raids, as they denounce, stigmatize and violate the rights of women.

Secondly, "radical abolitionism" was born in the 1960s and developed by such prominent feminist intellectuals as Kathleen Barry (1987), Carole Pateman (1995), or Catherine MacKinnon (1995). It views prostitution as one of the most intolerable forms of violence against women that denies all civil rights and violates the right to dignity of persons. From this perspective, patriarchal power and masculine sexual dominance would suppress the autonomy and the ability to consent of women who exercise prostitution, who are turned into mere objects of consumption. For radical abolitionist, no women would ever voluntarily become a prostitute; they would always be forced to become one either because they have been directly forced or because patriarchal society gives them no other way out.

\footnotetext{
${ }^{3}$ Approximately $50 \%$ of women in prison in the United States are for prostitution-related offenses (Aronson 2006, p. 378).
} 
In third place, at the end of the nineties' appeared what has been called as "neoabolitionism". This new form of abolitionism advocates for the punishment of the client of prostitution by criminalizing the request of prostitution as a criminal offence. It criminalizes the purchase of sexual services and other exploitation activities but leaves unpunished and decriminalized its offer. It welcomes the philosophy that inspires radical abolitionism but puts the spotlight on clients, who had been absent from debates on prostitution on previous issues.

Finally, what Heim and other authors categorize as "mixed" or "moderate abolitionism" seeks to overcome the criticisms that have been raised from pro-rights movements towards abolitionism about denial of sex workers agency. It recognizes the possibility of women engaging in prostitution on a voluntary basis. It also distinguishes between prostitution, smuggling and human trafficking, and avoids discussions about the dignity or lack of dignity of prostitutes, but, at the same time, considers prostitution contrary to the principle of equality and aims its eradication (Rubio 2008, pp. 90-92).

Sweden has become the first neo-abolitionist state with the passage of the Sexköpslag Act in 1999. ${ }^{4}$ The so-called Swedish model (exported to other countries such as Norway or I celand) has involved the criminalization of all activities that favor prostitution considering criminal offences with prison penalties, pimping, request of sexual services, or any other activity that favors prostitution. On the contrary, prostitutes are considered as victims of the criminal offence of prostitution and they are not criminalized.

The results of the implementation of this model are controversial. On the one hand, the Swedish Government has made several official reports highlighting the positive effects of the law. Thus, in the evaluation of the ban on the purchase of sexual services published in 2010 , the Swedish Government stated that prostitution had not increased in recent years and that there had been a decline in the number of women trafficked for the purpose of sexual exploitation. This is contrary to what would have happened in other neighboring countries where, according to the Swedish Government, prostitution and trafficking would have increased in the same period of time. The evaluation report also claimed to have had a deterrent effect on clients and a greater rejection towards prostitution by Swedish society (Government Offices of Sweden 2010, p. 9).

Gimeno (2012, p. 280) warns of the unreliability of these data and points out that, even accepting this decrease in total prostitution figures, it has been found that the conditions of those who continue to engage in this activity have get worse in Sweden, and other countries that have adopted neo-abolitionist policies. To sustain her argument, she cites a research carried out by British Channel 4, which concluded that when there is police pressure on clients, $65 \%$ of prostitutes reported working longer hours, and $40 \%$ much more hours, despite of which, $66 \%$ of them claimed to earn less. In addition, their safety measures were relaxed: $53 \%$ used less time to examine the client before getting into his car and $24 \%$ admitted having consented to perform "services" that they would otherwise have refused, mainly not using a condom.

On the other hand, authors such as Dodillet and Östergren (2012 p. 115-6) question the objectivity of the official data published by the Swedish Government and point out that it cannot be said that prostitution has declined since the implementation of the Law. They affirm that there has only been a shift from street prostitution to closed places, where prostitution is less visible and more difficult to detect. These authors warn about the negative effects of the new Swedish legislation, such as increasing the stigmatization of sex workers, their greater distrust of the authorities and the system, the reduction of the bargaining power of the collective, or the difficulty of the clients, now also penalized, to collaborate as witnesses in criminal proceedings

\footnotetext{
${ }^{4}$ Followed by Anti-Trafficking in Persons Act on 2002 and Anti-Pimping Act passed on 2005.
} 
against pimps or traffickers for fear of being denounced (Dodillet and Östergren 2012, pp. 140-143).

Despite the detection of these negative effects and the mentioned doubts about the real impact of the Swedish model on the decline in prostitution figures, neoabolitionism has become popular and has been designed as the ideal model to be followed by important sectors of the population and feminist movements. Even the European Parliament in a recent resolution on February the $26^{\text {th }}, 2014$, considers the neoabolitionist model applied in Sweden, I celand and Norway (the so-called Nordic model), the best model to achieve gender equality and fight against trafficking of women.

In the Spanish context, authors such as Victoria Sau (2007, p. 206) or Lidia Falcón (2007, p. 48) have been in favor of adopting an abolitionist model like in Sweden. However, authors such as Gimeno (2012, pp. 281-282) problematise the application of the Swedish system to our country. She points out that the dimensions of the phenomenon of prostitution are much larger in Spain, ${ }^{5}$ and it has also to be considered that in Sweden the policy of criminalizing demand has been combined with strong economic investments. For Gimeno, a budget allocation that would provide real alternatives to women who are prevented from undertaking prostitution would be essential should the model be implanted in Spain. She considers that such an investment is unrealistic in Spain, considering that no feminist Law has been wellsupported to date. ${ }^{6}$

\subsection{Pro-rights model}

Throughout the 1970s, movements for the recognition of the rights of sex workers emerged, many of them headed by the sex workers themselves. One of their main contributions has been the conceptualization of the term sexual work, which encompasses both prostitution and other works that use energy or sexual parts of the body as working tools, such as, pornography, erotic phones, erotic massages, or striptease (Heim 2011, pp. 244-247). The recognition of the status of workers is perceived as a necessary condition to be considered full members in society and to acquire all the citizenship rights that in current societies are attributed to people who participate in the labor market (J uliano 2004, p. 47).

By using the concept sex work, prostitution compares to other labor activities, although it is recognized that prostitution has its own special features that should be taken into account to differentiate from other types of work. From a pro-rights perspective, labor rights should be recognized to sex workers as well as they are recognized to other workers. Those movements argue that the debate about prostitution should move away from morality and focus instead on a debate about the recognition and protection of sex workers' rights. Considering that women can voluntarily choose to work in prostitution, the problem that they point out is the usual infringement of sex workers rights by clients, police, pimps and others.

Pro-rights movements considers it a priority to fight against the stigma of sex workers, "dedramatizing" prostitution and subtracting discussion from the moral debate. They argue that destroying the stigma of prostitutes would help to reach higher standards of freedom to women as it would help to eliminate the dichotomy good women/bad women that patriarchal power uses to control women (López and Mestre 2006, p. 118). Also recognizing the agency capacity of women and accepting

\footnotetext{
${ }^{5}$ Brufao (2008, p. 11) points out that between 300,000 and 600,000 women practice prostitution in Spain. ${ }^{6}$ The Swedish government is carrying out a policy of full employment not only in Sweden but also globally with the belief that if people have options of occupation they will not be forced to engage in prostitution. In this regard, in 2002 donated 1,000,000 euros to the International Labor Organization to combat global unemployment, and another $1,000,000$ euros to the economic community of West African countries for their implementation in plans to combat human trafficking (Heim and Monfort 2004, p. 120).
} 
women's decisions without paternalisms and accepting the decisions that women make about their own lives, can serve to achieve greater quotas of gender equality.

Pro-rights movements points out that the abolitionist models cannot give answers to the complex reality of prostitution as the latter usually don't differentiate between voluntary sex work from other realities such as trafficking of human beings. For prorights movements this distinction is basic to address efficiently a debate about prostitution, as public policies aimed at one and another reality should be different. The debate should center on the recognition of rights for both sex workers and victims of human trafficking but always taking into account that they are different realities and the performance of the public powers should be different in each case.

Smuggling, human trafficking, and prostitution are then different phenomena that sometimes match together but also can appear separately. This distinction is also welcomed in mixed or moderate abolitionism, and has been host to the Convention of the Council of Europe against Trafficking on Human Beings (2005). The main distinction between human trafficking and prostitution is the lack of freedom and autonomy that takes place in human trafficking because of the use of force, intimidation or deception. ${ }^{7}$ To pro-rights supporters, and also for the Council of Europe, trafficking of human beings violates human rights and should be persecuted and punish as a criminal offence, rights of victims should be recognized and damage done must be repaired.

Taking into account that prostitution is something totally different from trafficking, since there is no coercion or violence in prostitution, pro rights movement claim for the recognition and protection of sex worker's rights in carrying out the activity of prostitution. From this perspective, some of their demands are the recognition of agency of sex worker's, recognition of the right to good conditions in work, right to health, labor and social rights, or criminalization of any kind of violence against sex workers.

Pro-rights perspective seeks to repeal all norms that prohibit or criminalize prostitution, even the neoabolitionist laws that criminalize clients as they consider that they reproduce the stigma attached to sex workers, make prostitution clandestine, leave workers in worse conditions and reduce their income.

Some countries like Germany or Holland have passed laws that legalize prostitution but none of them have recognized all the claims of pro-rights movement or has recognized social and labor rights for sex workers in equal conditions as other workers. As seen before, this countries allow prostitution but also limit its practice through zonification and they do not have a uniform regulation since they have delegated much of its regulation in local authorities.

\section{Spanish model: prostitution in Barcelona after the Bylaw on Coexistence}

At the end of 2005, the Barcelona City Council passed the Bylaw on Measures to Encourage and Ensure Coexistence among Citizens in Public Spaces, which prohibits and sanctions the offering, negotiating or requesting of paid sexual services in public spaces. With its introduction, Barcelona became the first city of Spain that opted to sanction the practice of prostitution. Prior to this, the Danger and Social Rehabilitation Act (1970), had prohibited the practice of prostitution on the streets, but it was later repealed when the Spanish Constitution came into effect in 1978.

\footnotetext{
${ }^{7}$ Article 4 of the Convention of the Council of Europe against Trafficking on Human Beings (2005) defines human trafficking as follows: “'Trafficking in human beings' shall mean the recruitment, transportation, transfer, harbouring or receipt of persons, by means of the threat or use of force or other forms of coercion, of abduction, of fraud, of deception, of the abuse of power or of a position of vulnerability or of the giving or receiving of payments or benefits to achieve the consent of a person having control over another person, for the purpose of exploitation. Exploitation shall include, at a minimum, the exploitation of the prostitution of others or other forms of sexual exploitation, forced labour or services, slavery or practices similar to slavery, servitude or the removal of organs".
} 
Following Barcelona, other Spanish local governments, such as those of Badalona, Castelldefels, Girona, Lleida, Valencia, Málaga and Granada, have passed bylaws that prohibit street prostitution by fining both sex workers and clients.

3.1. The concept of civility and previous context to the passing of Barcelona's Bylaw on Coexistence

The making and later passing of the bylaw to encourage and ensure coexistence among citizens in public spaces in Barcelona was the result of a process in which the concept of civility played a central role (Fernández et al. 2009, 35). In fact, this bylaw is popularly known in Barcelona as the Bylaw on Civility and the concept of civility has become a new fundamental value for the coexistence among citizens.

The word civility started to become more common in the months preceding the passing of the bylaw, placing emphasis on those behaviours considered undesirable or immoral by the powerful sectors (Arella 2009, 81-82). The role played by the media was crucial: it presented Barcelona as a city out of control, where anti-social actions that went against social peace were continuously taking place. Such actions demanded strong measures to counteract them by the local government. As an example, in July 2005, the La Vanguardia newspaper dedicated 32 front pages to point out "deviant" behaviours that supposedly threatened peaceful coexistence (Pisarello and Asens 2011, 96).

The term civility was coined to justify stricter regulations on coexistence by prohibiting a series of activities that had previously been considered legal, such as begging, consumption of alcohol or prostitution in public spaces.

In that context, in 2005 the Barcelona City Council set up an Interdepartmental Political and Technical Committee to study issues related to prostitution in public spaces. This committee was split into two opposing positions. On the one hand, the Department of Safety suggested intervening from a security standpoint. On the other hand, the Department for Women put pressure on the central government to regulate sex work and include it in the Workers' Statute (Arella et al. 2007, 81-82). In the end, the approach to prostitution from the punitive, controlling and security perspective that favoured the prohibition and sanction of prostitution in public spaces through the bylaw was successful.

3.2. Content of the Bylaw on Coexistence related to the prohibition of the practice of prostitution in public spaces

On the 23rd December 2005, the Barcelona City Council passed the Bylaw on Measures to Encourage and Ensure Coexistence among Citizens in Public Spaces in Barcelona. This bylaw was presented as an "effective tool to face new situations and circumstances that may affect or disrupt peaceful coexistence and that have recently been taking place in Barcelona, just as in any other major European city, in today's increasingly globalised world".

Offering sexual services on the streets can be found among the activities that the bylaw considers as potentially detrimental for coexistence: "the bylaw prevents the practice of prostitution on the streets affecting coexistence among citizens and at the same time establishes social measures such as the Programme for a Comprehensive Approach to Sex Work and its Agency, meant to lead to a way out of the current situation". With it, the Barcelona City Council for the first time faced up to the problems resulting from the occupation of public spaces for the offering or requesting of sexual services. Until then, it was an area in which neither the State nor the autonomous regions had decided to act upon (Gracia 2008, 100).

This bylaw has four sections dedicated to the use of public spaces for the offering or requesting of sexual services. Sections 39 and 40 list prohibited behaviours and their corresponding fines: 
I) Prohibition of the offering or requesting of sexual services

Section 39.1 prohibits offering, requesting, negotiating or accepting, directly or indirectly, paid sexual services in public spaces when these practices exclude or limit the compatibility of the normal uses of the public space.

Section 40 stipulates that those persons who breach the previous provision will just be reminded by police officers, without being fined, that these practices are forbidden. Only in the case that they persist with their activities after being warned by the police or do not leave when requested, will they be penalised for committing a very serious offence of disobedience to authority with fines between 1,500.01 and 3,000 euros.

II) Prohibition of the offering or requesting of sexual services less than 200 metres from a school

In section 39.2 the bylaw prohibits the offering, requesting, negotiating or accepting of paid sexual services in public spaces when such activities are carried out in areas located less than 200 metres from schools or educational centres where formal education takes place. In this case, as it did in the previous one, the bylaw stipulates that police officers will remind those persons that said practices are forbidden and will recommend public and private institutions that offer social assistance and any other help that might be needed. In the case that the person continues to offer or request sexual services and does not leave when asked to do so, they will be penalised for committing a minor offence with fines up to 750 euros.

It should be pointed out that the 750 euros fine stipulated for the latter case is considerably lower than the one stipulated for the former case, which specified fines ranging from 1,500 to 3,000 euros. The proportionality between the stipulated fines is, therefore, questionable, considering that the offence consisting in offering or requesting sexual services at less than 200 metres from a school seems to be, at first glance, a more serious one than the one carried out at a larger distance; however, the stipulated fine is lower. It should be also noted that the terms "school" or "educational centre" are excessively vague concepts and that the enforcement of this section is not linked to either school hours or the presence of minors.

III) Prohibition of maintaining paid sexual relations in public spaces

Section 39.3 of the bylaw specifically prohibits maintaining paid sexual relations in public spaces. Section 40.3 stipulates that such behaviour will be considered a very serious offence and will be penalised with fines between 1,500 and 3,000 euros.

This provision sanctions behaviour consisting of maintaining sexual relations in public spaces only when it is paid for. That means that such behaviour is only penalised when carried out by a person who practices prostitution and not when carried out by any other person. Therefore, the regulation does not aim to sanction anyone for causing distress by having sexual relations in public spaces, but to sanction the practice of prostitution.

\subsection{The grounds for the prohibition of prostitution in the bylaw}

Section 38 of the bylaw lists the grounds that justify the prohibition of the offering or requesting of sexual services in public spaces:

- To prevent minors from witnessing such practices as the offering or requesting of sexual services on the streets;

- To ensure peaceful coexistence;

- To avoid mobility problems on thoroughfares; and

- To prevent the exploitation of certain groups. 
This bylaw aims, firstly, to prevent minors from witnessing such practices as the offering or requesting of sexual services on the streets. As such, it is forbidden to offer, negotiate or request paid sexual services in public spaces, or maintain paid sexual relations in public spaces. It would be preferable to have better definitions of both this goal and the undesirable activities, seeing as the negotiating, offering or requesting of sexual services basically consists of a conversation between two people, without there being anything to particularly differentiate it from any other conversation carried out in public spaces. Two people talking on the street, either negotiating or closing a deal, is a familiar sight to minors and one which they will not connect to any nefarious practices on their own. It is hard to justify banning people from talking on the streets based on the assumption that the content of the conversation will be damaging to any minors that are present.

On the contrary, if the intent is to prevent minors from witnessing scenes of sexual content, then there should therefore be a clearer definition of the behaviour to be sanctioned. Also, it should be taken into consideration that the bylaw prohibits behaviour consisting of maintaining sexual relations in public spaces only when it is paid for and not when it is motivated by love or desire. Consequently, it can be concluded that this was probably not the goal of the regulation, seeing as it would be hard for a minor to know if such sexual relations entail an economic transaction or not; however, only those involving a previous economic agreement are sanctioned.

Secondly, it is questionable that the content of a conversation may endanger the peaceful coexistence, mobility or protection of minors, as talking on the streets is as common a practice in Barcelona as in any other city. It is hard to determine the content of a conversation without listening to it; however, it is too easy to fabricate it based upon preconceived ideas or stereotypes such as the speaker's ethnical origin, their way of dressing or moving, or their presence in a particular street or area. Such assumptions would probably violate the right to equality and to non-discrimination.

Thirdly, this regulation aims to "prevent the exploitation of certain groups". This point is probably one of the most controversial and more often invoked in order to justify the prohibition of prostitution on the streets. This bylaw aims to prevent sexual exploitation, and as such it contemplates the real possibility that a person who practices prostitution finds themselves in the situation of human trafficking for the purpose of sexual exploitation. However, in view of this possible rights violation, the Barcelona City Council opts to fine the person offering their services, which is to say, the possible victim of exploitation. It cannot be said, therefore, to be a measure that prevents, in itself, sexual exploitation, quite the opposite, in fact, as it may lead to a re-victimisation, a higher vulnerability and to the understandable mistrust of the victim towards the police forces. Fining a possible victim of a crime does not necessarily prevent sexual exploitation, but can lead to a further violation of their rights.

On top of this, the bylaw does not sanction the "exploiter", that is, the trafficker. Human trafficking for the purpose of sexual exploitation is a very serious crime punishable by a prison sentence of up to eight years as defined in section 177 bis of the Spanish Criminal Law Code. Trafficking in human beings cannot be punished with sanctions of an administrative nature. Instead, it should be punished criminally, otherwise it diminishes the seriousness of the violation of rights caused by the crime. This is the reason why an administrative sanction is also not an appropriate way for combating sexual exploitation.

\subsection{Appealing against the Bylaw on Coexistence}

The bylaw was appealed against by a considerable number of organisations and associations, divided into four groups, who each lodged a different appeal. In their appeals, these associations requested that the bylaw should be declared null in its entirety. They also raised the question of whether several of its sections were unconstitutional. The appeals were dismissed almost entirely by four sentences set 
down by section 5 of the High Court of Justice of Catalonia (TSJC) and this was confirmed by the Supreme Court in the rulings of 18th July 2011, 18th October 2011 and 25th October 2011.

\subsection{Modification of the Bylaw on Coexistence}

After enforcing the bylaw for more than six years, on 18th July 2012, the Barcelona City Council announced the modification of the bylaw's sections relating to prostitution in order to "provide a solution for this taking place in public spaces that in many cases leads to a violation of the most fundamental human rights and the exploitation of the marginalised conditions in which many people find themselves" (Ajuntament de Barcelona 2012).

The modification of sections 39 and 40 of the bylaw was presented as an instrument that aimed to "provide unambiguous tools for the application of stricter sanctions on clients and on any person promoting prostitution, without criminalising the people who practice prostitution" (Ajuntament de Barcelona 2012).

First, the modification of the bylaw now permitted the direct sanctioning of sex workers for the offering or accepting of paid sexual services in public spaces since it took away the previous need for giving a warning before being able to impose a fine.

Offering or accepting sexual services in public spaces is penalised, since the modification came into effect, with fines between 100 and 300 euros, and between 300.01 and 750 euros when such activities are carried out less than 200 metres from a school. The possibility of substituting these fines for alternative measures, as long as no appeals are filed against it, is introduced. In these cases, it should be taken into consideration that one of the reasons used to determine the appropriateness of the substitution is whether it is a repeat offence, and a person who regularly practices prostitution is frequently fined more than once for it.

Second, the new legal text aggravates the behaviour of potential clients. The requesting or negotiating of paid sexual services in public spaces are penalised with fines between 1,000 and 1,200 euros, and between 1,200.01 and 1,500 euros when carried out less than 200 metres from a school.

Third, the modification includes the prohibition of "any behaviour that favours or promotes prostitution or any other form of sexual exploitation", including the approaching of clients. The fines stipulated for this are the same as those for clients mentioned in the previous paragraph.

Last, the modification maintains the prohibition of carrying out paid sexual relations in public spaces and the fines of 1,500.01 to 3,000 euros remain the same.

The modification of the bylaw has been very criticised by the sex workers themselves and by a few of the organisations specialising in their care and in defence of human rights. Its approval resulted in the Indignant prostitutes: voices against the prohibition of the rights of women on the street campaign, and was carried out by several groups, associations, neighbours and women who practice prostitution.

In their internal report of 17th October 2011, the Department of Prevention, Safety and Mobility of the Barcelona City Council advised against the implementation of the modification claiming that "it would, among other things, complicate the access to standardised public services for people who practice prostitution". The report also stated that police measures on their own "will not banish either the practice of prostitution nor its demand, but instead will result in prostitution being covered up or moved to a less visible place, with a greater risk that the criminal networks remain unpunished".

The Ombudsman service of Barcelona was also against the modification of sections 39 and 40 of the bylaw claiming that in its formation the relevant organisations had not been consulted, nor had the internal report from the Department for the 
Prevention, Safety and Mobility of 17th October 2011 advising against such modification been taken into consideration (Síndica de Greuges de Barcelona 2012).

3.6. Statistics published by the Barcelona Local Police in reference to the prohibition of prostitution in public spaces

The bylaw punishes the offering of paid sexual services (carried out by the sex worker), the requesting of paid sexual services (carried out by the client) or the fact of having paid sexual relations (carried out by both the client and the sex worker), as long as such activities take place in a public space. The Barcelona Local Police has published their data on the fines imposed for this type of offence during 2011, 2013 and 2014 in their annual activity reports (Guàrdia Urbana de Barcelona 2011, 2012, 2013, 2014). In 2011, 627 fines were imposed in Barcelona city for the offering of sexual services. There is no record of any fines being imposed for the requesting of sexual services or for carrying out paid sexual relations in public spaces. During 2013 and 2014, 1,052 and 741 fines were imposed respectively for the offering of sexual services; 546 and 316 fines for the requesting of sexual services; and 252 and 130 fines for carrying out paid sexual relations in public spaces.

This means that in 2011 the $100 \%$ of the fines were imposed on sex workers for offering their services and no fines were imposed on their clients. In 2013, 56.9\% of the fines were imposed on sex workers for offering their services, $29.5 \%$ on clients for the requesting of such services and $13.6 \%$ of the fines for the carrying out of paid sexual relations in public spaces, of which half, that is, $6.8 \%$, were given to sex workers and the other $6.8 \%$ to clients. In 2014, similar percentages are found: $62.4 \%$ of the fines were imposed on sex workers for offering their services (which represents a small increase in the percentage), $26.6 \%$ of the fines were imposed on clients for the requesting of such services and $11 \%$ of the fines were for carrying out paid sexual relations in public spaces.

The number of fines given to people who practice prostitution for the offering of paid sexual services in public spaces represent more than half of those imposed for breaking the bylaws relating to prostitution and are approximately twice those that were given to clients for the requesting of sexual services. If the fines imposed for carrying out paid sexual relations in public spaces were divided equally between the clients and the people who practice prostitution for the requesting and offering of sexual services and were added to those that they received respectively, then the fines imposed to sex workers represent a larger number than those imposed to clients: two out of three fines sanction sex workers while one out of three sanctions clients.

\section{Conclusions}

Barcelona's Bylaw on Coexistence is the first regulation in Spain that, since the restoration of the constitutional democracy in 1978, opted to prohibit prostitution in public spaces and sanction both sex workers and their clients. Many other cities have followed Barcelona's example and have passed similar regulations. The passing of this type of bylaw avoids the controversy that would follow the debate and passing of either a national law that regulates sex work as a labor activity or a law that directly prohibits prostitution.

It has been questioned whether the bylaw's prohibitive and punitive nature for the regulation of prostitution is justified, since it does not seem to achieve the objectives set out for it. It does not appear to be an adequate measure to fight human trafficking as it sanctions the possible victims instead of protecting them. Also, human trafficking is a serious crime that is defined in Spanish Criminal Law and is punishable by a prison sentence of up to eight years, which is why it should not be punished with sanctions of an administrative nature. 
Thanks to an analysis of the statistics published by the local police in charge of the enforcement of the bylaw, it has been confirmed that despite the fact that the bylaw aims to avoid criminalization of people who practice prostitution, the truth is that they are treated more strictly than the clients. Sex workers continue to receive the greater part of sanctions and they receive two out of every three fines imposed in the enforcement of the bylaw's sections that prohibit prostitution in public spaces.

\section{References}

Ajuntament de Barcelona, 2005. Medidas para fomentar y garantizar la convivencia ciudadana en el espacio público de Barcelona. Boletín Oficial de la Provincia de Barcelona [online], 20, anexo I. 24 J anuary 2006. Available from: http://ajuntament.barcelona.cat/ordenances/sites/default/files/pdf/convivenci acast.532.doc [Accessed 15 March 2018]. Modified by Ayuntamiento de Barcelona on 12 May 2011 and 16 August 2012 and by Sentencia del Tribunal Supremo [Sentence of the Supreme Court] of 23 March 2015.

Ajuntament de Barcelona, 2012. L'Ajuntament de Barcelona sancionarà amb més contundència els clients de la prostitució [online]. Press release, 18 July. Available from: http://ajuntament. barcelona.cat/premsa/2012/07/18/lajuntament-debarcelona-sancionara-amb-mes-contundencia-els-clients-de-la-prostitucio/ [Accessed 28 March 2018].

Arella, C., 2009. Gestión del espacio público y derecho a la ciudad. El caso del trabajo sexual. In: Vanesa Valiño, ed., Defender y repensar los derechos sociales en tiempo de crisis. 4a edición del curso de derechos sociales [online]. Barcelona: Observatori DESC. Available from: http://observatoridesc.org/sites/default/files/Defender_repensar_derechos_so ciales_lib_DESC_AAVV_sp_1.pdf [Accessed 28 March 2018].

Arella, C., et al., 2006. Una aproximación a la vulneración de los derechos humanos de las trabajadoras sexuales en la ciudad de Barcelona. Universidad de Barcelona: Observatori del Sistema Penal i els Drets Humans.

Arella, C., et al., 2007. Los pasos (in) visibles de la prostitución. Estigma, persecución y vulneración de derechos de las trabajadoras sexuales en Barcelona. Bilbao: Virus.

Aronson, G., 2006. Seeking a consolidated feminist voice for prostitución in the US. Rutgers J ournal of Law \& Urban Policy [online], 3 (3), 357-388. Available from:

http://policeprostitutionandpolitics.net/pdfs_all/Academic_pro_decrim_articles _pdfs/2006\% 20\% 20Seeking\% 20A\% 20Consolidated $\% 2$ Feminist $\% 20$ Voice $\% 2$ 0for\% 20Prostitution\%20in\%20America.pdf [Accessed 15 March 2018].

Barry, K., 1987. La esclavitud sexual femenina. Barcelona: La Sal.

Brufao Curiel, P., 2008. Prostitución y políticas públicas: entre la reglamentación, la legalización y la abolición. Estudios de progreso [online], 33. Fundación Alternativas. Available from:

http://www. fundacionalternativas.com/public/storage/estudios_documentos_a rchivos/xmlimport-jPZHqj.pdf [Accessed 15 March 2018].

Convention on Action against Trafficking in Human Beings. Council of Europe Treaty Series - No. 197 [online]. Warsaw, 16 May 2005. Available from: https://www.coe.int/en/web/conventions/full-list/-/conventions/treaty/197 [Accessed 30 November 2017]. 
Covre, P., 2004. ¿De prostitutas a "sex workers"? In: R. Osborne, ed., Trabajador@s del sexo. Derechos, migraciones y tráfico en el siglo XXI. Barcelona: Bellaterra, pp. 237-244.

Di Nicola, A., 2007. Ponencia para el Estudio de la Situación Actual de la Prostitución en España Comisión Mixta de los Derechos de la Mujer y la Igualdad de Oportunidades. Boletín Oficial de las Cortes Generales [online], 379, of 24 May. Sección Cortes Generales. Otros textos. Comisiones Mixtas, Subcomisiones y Ponencias. Available from:

http://www.congreso.es/public oficiales/L8/CORT/BOCG/A/CG_A379.PDF [Accessed 15 March 2018], pp. 220-224.

Dodillet, S., and Östergren, P., 2012. Ley sueca sobre la compra de sexo: presuntos éxitos y resultados demostrables In: C. Villacampa, ed., Prostitución, ¿hacia la legalización? Valencia: Tirant lo Blanch.

Falcón, L., 2007. Ponencia para el Estudio de la Situación Actual de la Prostitución en España, Comisión Mixta de los Derechos de la Mujer y la I gualdad de Oportunidades. Boletín Oficial de las Cortes Generales [online], 379, of 24 May. Sección Cortes Generales. Otros textos. Comisiones Mixtas, Subcomisiones y Ponencias. Available from: http://www.congreso.es/public_oficiales/L8/CORT/BOCG/A/CG_A379.PDF [Accessed 15 March 2018], pp. 48-56.

Fernández, C., et al., 2009. Construcció del civisme i gestió de la convivència a l'espai públic de la ciutat de Barcelona [online]. Research report. Prepared by Observatori del Sistema Penal i els Drets Humans de la Universitat de Barcelona. Available from: http://www.fbofill.cat/sites/default/files/1602.pdf [Accessed 16 March 2018].

Gimeno, B., 2012. La prostitución. Aportaciones para un debate abierto. Barcelona: Bellaterra.

Government Offices of Sweden, 2010. Selected extracts of the Swedish government report SOU 2010: 49: The Ban against the Purchase of Sexual Services. An evaluation 1999-2008 [online]. Trans.: M.L. Key, J. Evans. Available from: http://www. government.se/4a4908/contentassets/8f0c2ccaa84e455f8bd2b7e 9c557ff3e/english-translation-of-chapter-4-and-5-in-sou-2010-49.pdf [Accessed 16 March 2018].

Gracia Retortillo, R., 2008. Convivencia ciudadana, prostitución y potestad sancionadora municipal. El caso de Barcelona. QDL Cuadernos de Derecho Local, 17, pp. 99-133.

Guàrdia Urbana de Barcelona, 2011. Informe d'activitat 2011 [online]. Available from: http://www.bcn.cat/guardiaurbana/pdf/memoria/Guardia-UrbanaBarcelona-Informe-Activitats-2011-ca.pdf [Accessed 15 March 2018].

Guàrdia Urbana de Barcelona, 2012. Informes de gestió 2012 [online]. Available from: http://www.bcn.cat/guardiaurbana/pdf/memoria/Guardia-UrbanaBarcelona-Informe-Activitats-2012-ca.pdf [Accessed 15 March 2018].

Guàrdia Urbana de Barcelona, 2013. Informe de gestió 2013 [online]. Available from: http://www.bcn.cat/guardiaurbana/pdf/memoria/Guardia-UrbanaBarcelona-Informe-Activitats-2013-ca.pdf [Accessed 15 March 2018].

Guàrdia Urbana de Barcelona, 2014. Informe de gestió 2014 [online]. Available from: http://www. bcn.cat/guardiaurbana/pdf/memoria/Guardia-UrbanaBarcelona-Informe-Activitats-2014-ca.pdf [Accessed 15 March 2018]. 
Heim, D., 2011. Prostitución y derechos humanos. Cuadernos electrónicos de Filosofía del Derecho [online], 23, 234-251. Available from: https://ojs.uv.es/index.php/CEFD/article/view/716/472 [Accessed 15 March 2018].

Heim, D., and Monfort, N., 2004. Prostitució i polítiques públiques: anàlisi i perspectives d'un conflicte històric. Especial referència a la situació en els Països Baixos i Suècia. Revista Catalana de Seguretat Pública, 15, 109- 119.

Juliano Corregido, M.D., 2004. El peso de la discriminación: Debates teóricos y fundamentaciones. In: R. Osborne, ed., Trabajador@s del sexo. Derechos, migraciones y tráfico en el siglo XXI. Barcelona: Bellaterra, pp. 43-56.

Kavemann, B., 2012. Resultados del Estudio sobre el Impacto de la Ley sobre Prostitución en Alemania. In: C. Villacampa, ed., Prostitución: ¿hacia la legalización? Valencia: Tirant lo Blanch.

Lag (1998:408) om förbud mot köp av sexuella tjänster [Law 1998: 408 on the ban of purchase of sexual services, also referred to as Sexköpslag Act]. Justice Department of the Government of Sweden, 1999.

López, M., and Mestre, R., 2006. Trabajo Sexual. Reconocer derechos. Valencia: La Burbuja.

MacKinnon, C.A., 1995. Hacia una teoría feminista del Estado. Madrid: Cátedra, coll. Feminismos.

Maqueda, M.L., 2009. Prostitución, feminismos y derecho penal. Granada: Comares, coll. Estudios de Derecho Penal y Criminología.

Mestre, R., 2004. Las caras de la prostitución en el Estado español: Entre la Ley de Extranjería y el Código Penal. In: R. Osborne, ed., Trabajador@s del sexo. Derechos, migraciones y tráfico en el siglo XXI. Barcelona: Bellaterra, pp. 245-261.

Nicolás, G., 2008. El tratamiento jurídico de la prostitución en el Estado español: ¿abolicionismo o reglamentarismo neoliberal? La prostitución: actualidad y repercusiones sociales. Revista Galega de Seguridade Pública, 11.

Organic Act 10/1995, dated 23 November 1995, on the Criminal Code, 2013 [online]. Madrid: Technical General Secretariat of the Ministry of J ustice, Government of Spain. Available from: www.legislationline.org/documents/id/18769 [Accessed 15 March 2018].

Pateman, C., 1995. El contrato sexual. Trans.: M.L. Femenías, revised by M.X. Agra. Barcelona: Anthropos.

Pisarello, G., and Asens, J., 2011. No hay derechos. La ilegalidad del poder en tiempos de crisis. Barcelona: I caria.

Resolution of 26 February on sexual exploitation and prostitution and its impact on gender equality (P7_TA(2014)0162) [online]. European Parliament, 2014. Available from: http://www. europarl.europa.eu/sides/getDoc.do?pubRef=//EP//NONSGML+TA+P7-TA-2014-0162+0+DOC+PDF+V0//EN [Accessed 15 March 2018].

Rey Martínez, F., Mata, R.M., and Serrano Argüello, N., 2004. Prostitución y Derecho. Cizur Menor: Aranzadi.

Rubio, A., 2008. La teoría abolicionista de la prostitución desde una perspectiva feminista. In: I. Holgado, ed., Prostituciones. Barcelona: Icaria. 
Sau, V., 2007. Ponencia para el Estudio de la Situación Actual de la Prostitución en España, Comisión Mixta de los Derechos de la Mujer y la I gualdad de Oportunidades. Boletín Oficial de las Cortes Generales [online], 379, of 24 May. Sección Cortes Generales. Otros textos. Comisiones Mixtas, Subcomisiones y Ponencias. Available from: http://www.congreso.es/public_oficiales/L8/CORT/BOCG/A/CG_A379.PDF [Accessed 15 March 2018], p. 206.

Síndica de Greuges de Barcelona, 2012. Decisió de la Síndica de Greuges referent a l'actuació d'ofici oberta arran de la modificació dels articles 39 i 40 de l'ordenança de mesures per fomentar i garantir la convivencia ciutadana a l'espai públic [online]. Available from: http://sindicadegreugesben.cat/pdf/resolucions/res_641373263993.pdf [Accessed 16 March 2018].

Villacampa, C., 2012. Políticas de criminalización de la prostitución: análisis crítico de su fundamentación y resultados. Revista de Derecho Penal y Criminología [online], 3a época, 7. Available from: http://e-

spacio.uned.es/fez/eserv.php?pid=bibliuned: revistaDerechoPenalyCriminologi a-2012-7-2030\&dsID=Documento.pdf [Accessed 16 March 2018], pp 81-142.

Wijers, M., 2004. Delincuente, víctima, mal social o mujer trabajadora: perspectivas legales sobre la prostitución. In: R. Osborne, ed., Trabajador@s del sexo. Derechos, migraciones y tráfico en el siglo XXI. Barcelona: Bellaterra, pp. 209-222. 